\title{
Notes on the history of geophysics in the Ottoman Empire
}

\author{
F. Ozcep ${ }^{1}$ and T. Ozcep ${ }^{2}$ \\ ${ }^{1}$ Department of Geophysical Engineering, Istanbul University, 34850 Avcilar, Istanbul, Turkey \\ ${ }^{2}$ Sirinevler Mehment Sen School, Ministry of National Education, Istanbul, Turkey \\ Correspondence to: F. Ozcep (ferozcep@istanbul.edu.tr)
}

Received: 13 June 2014 - Revised: 6 August 2014 - Accepted: 11 August 2014 - Published: 5 September 2014

\begin{abstract}
In Anatolia, the history of geophysical sciences may go back to antiquity (600 BC), namely the period when Thales lived in Magnesia (Asia Minor). In the modern sense, geophysics started with geomagnetic works in the 1600s. The period between 1600 and 1800 includes the measurement of magnetic declination, inclination and magnetic field strength. Before these years, there is a little information, such as how to use a compass, in the Kitab-i Bahriye (the Book of Navigation) of Piri Reis, who is one of the most important mariners of the Ottoman Empire. However, this may not mean that magnetic declination was generally understood. The first scientific book relating to geophysics is the book Fuyuzat-i Miknatissiye that was translated by Ibrahim Müteferrika and printed in 1731. The subject of this book is earth's magnetism. There is also information concerning geophysics in the book Cihannuma (Universal Geography) that was written by Katip Celebi and in the book Marifetname written by Ibrahim Hakki Erzurumlu, but these books are only partly geophysical books. In Istanbul the year 1868 is one of the most important for geophysical sciences because an observatory called Rasathane-i Amire was installed in the Pera region of this city. At this observatory the first systematic geophysical observations such as meteorological, seismological and even gravimetrical were made. There have been meteorological records in Anatolia since 1839. These are records of atmospheric temperature, pressure and humidity. In the Ottoman Empire, the science of geophysics is considered as one of the natural sciences along with astronomy, mineralogy, geology, etc., and these sciences are included as a part of physics and chemistry.
\end{abstract}

\section{Introduction}

There are two approaches to the discussion of the history of geophysics: the historical and the geophysical. From the historical point of view, the present work is a synthesis of separate (or independent) historical books or papers referring to geophysical ideas and scientific institutions in the Ottoman Empire. Various sources for the history of geophysical sciences in this country have been provided by researchers such as Adivar (1942); Akyol (1940), Brinkman (1981); Çölasan (1960); Demirel (1982); Dizer (1977, 1993a, b); Kandilli Observatory (1961); Sipahioglu (1957); Ozcep and Ozcep (1994); Ozdogan (1975); Ozemre (1982); Özçep and Orbay (1997). From the geophysical point of view, the historical geophysical data are important for time-dependent geophysical work such as seismology, meteorology, geomagnetism, etc., and these data were compiled and investigated for geomagnetism by Ozdogan et al. (1981) and for seismology by Soysal et al. (1981). In this paper, we give a short account of how the science of geophysics developed in Istanbul (Turkey) since 1600 with its main ideas, institutions and pioneers.

\subsection{Philosophical point of view for geophysical sciences}

Scientists are engaged in practising science. They are seldom concerned with the conceptual or philosophical foundation of what they are doing. They employ concepts and statements to express the results of their findings, construct hypotheses or theories to account for the data they have established by means of observation or experiment, but they rarely stop to think about the nature of these mental and physical operations. The logical approach to science is variously named "methodology" or "philosophy of science". The method of 


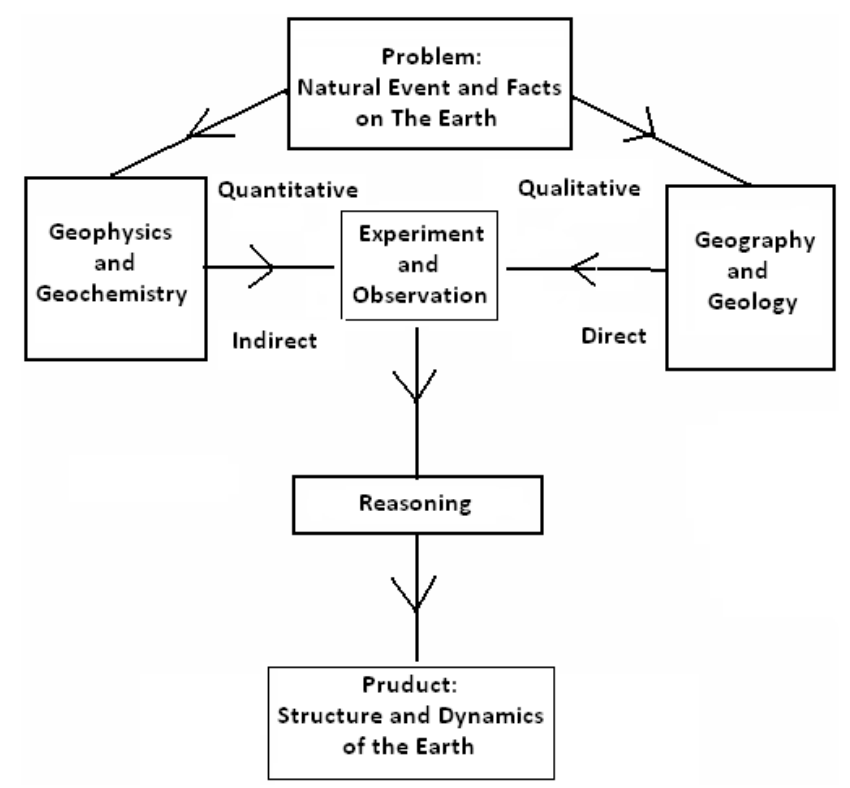

Figure 1. Geophysical approach to solving earth-related problems.

science forms a part of the philosophy of science. In addition to the logic (or philosophy) of science, there is the history of science which traces the development of science (Yildirim, 1971).

The aim of philosophy (and/or history) of (geophysical) science is to work out an understanding of (geophysical) science, particularly of its method and the procedures it involves. It is important to understand science for at least two reasons: for its practical effects and for its intellectual value.

As Schroder (1981) points out, we begin with one of the most important questions: "What led to the establishment of geophysics as a separate discipline?". The answer to this question can be found in the studies of the history and philosophy of geophysical sciences.

Before geophysical science came into being in its modern meaning, there were two branches of earth sciences, namely, geology and geography. In our opinion, there are three developments (or evolutionary) periods which explain the history of geoscientific research: "graphe", "logos" and "science". In the graphe period, every natural event or fact such as earthquakes, rivers, and storms are observed from a descriptive point of view. The main feature of this period is its "qualitative" nature (see Table 1). The basic form of geography appears in the history of this period.

The second period (logos) is a "transition" period, because it has both descriptive and explanatory characteristics. Its main characteristic is represented by a primitive form of geology (see Table 1). In the history of earth sciences, the last and the most recent development period is called the science period. Science is defined as a knowledge-generating activity based on facts of controlled observation (or experiment) and reasoning by which empirically verifiable general-
Table 1. Historical development periods of earth sciences.

\begin{tabular}{lll}
\hline Properties & Periods & Related discipline \\
\hline Qualitative & Graphe & Geography \\
Quantitative/qualitative & Logos & Geology \\
Quantitative & Science & Geophysics \\
\hline
\end{tabular}

izations (connecting, describing, and ideally explaining those facts) are formed and tested. The feature of this period is mainly quantitative. This characteristic is represented by the geophysical sciences. The period extends from Gilbert to the present time. One of the most important features of the period is the controlled and systematic "measurement" (or experiment) and "reasoning". In Table 1, the historical development (evolutionary) periods of geoscience and its features are given. The geophysical approach to solving problems relating to earth is given in Fig. 1. As it is known, the word "geophysics" is derived from the Greek "Gaia" (the goddess of earth) and "Physis" (nature). In its widest sense geophysics is the physics of earth and the space immediately surrounding it and the interactions between earth and extraterrestrial forces and phenomena. It consists of a number of interlocking sciences dealing with physical properties, its interior, its atmosphere, oceans, glaciated areas, its age and motions, and the practical applications of the acquired knowledge (Landesberg, 1986).

\subsection{Historical point of view: classical era for geophysics}

This part of paper is divided into two parts. The first part presents a framework for Anatolian science. The second part relates to the sciences as found in Islamic palaeogeography.

\subsubsection{Philosophy and science in Anatolia}

Philosophy and science in Anatolia began in the colonies along the west coast of Asia Minor in the seventh century BC. The Ionian school of thought assumed that the universe is natural and explicable by rational inquiry. This school was introduced by the Ionian nature philosophers of Asia Minor. Thales of Miletus (580 BC), one of the earliest natural philosophers, pictured earth as a flat disc, floating on water. Another Ionian philosopher, Anaximander (611-547 BC), was interested in geography. He represented the details of the surface of earth by means of maps (Singer, 1959; Dampier, 1959; Adams, 1954; Liner, 1997).

Ancient views of earthquakes and volcanic eruptions were introduced by Aristotle (384-322 BC) and Strabo (64 BC$A D 21)$. These views were valuable as historical records but do not discuss the causes of these events. Aristotle (384322 BC) claimed that volcanic explosions and earthquakes are caused by spasmodic motions of winds that move underground. 


\subsubsection{Sciences in Islamic palaeogeography}

Islam came face to face with the sciences of antiquity whose heritage had been preserved in centres which now became a part of the Islamic world. Alexandria had been a major centre of sciences and learning for centuries (Zahoor, 2000).

The knowledge of minerals and rocks was introduced and synthesized by Ibn Sina (Avicenna) in his Kitab al-Shifa (The Book of Healing, printed in 1027). Al-Biruni (973-1048) likewise in his study of India turned to the natural history and even geology of the region, describing correctly the sedimentary nature of the Ganges Basin. He also wrote the most outstanding Muslim work on mineralogy (Zahoor, 2000). Ibn Sina was the most famous physician, philosopher, encyclopedist, mathematician and astronomer of his time. His major contribution to medical science was his famous book alQanun fi al-Tibb, known as "The Canon" in the West. His treatise on minerals was one of the main sources of geology.

Al-Biruni was one of the outstanding natural scientists in medieval times. In his book Kitab-al-Jamahir he introduced and discussed the properties of various precious stones. In the field of earth sciences, al-Biruni contributed notes on geological eruptions (Zahoor, 2000).

Abu 'Abdallah al-Idrisi was the foremost among Muslim geographers. His 12th century maps are among the great achievements of Islamic science. Al-Idrisi was educated in Cordova, Spain. Muslim geographers in his time had already made accurate measurements of earth's surface, and several maps of the whole world were available (Zahoor, 2000).

The nautical compass, used by Muslim sailors, was introduced from China. This magnetic instrument was known to Muslim seafarers before the 10th century and probably was not considered very important in the East, because the skies over the Indian Ocean were usually very clear, especially during the times that Muslim mariners sailed. The earliest documented Arabic use of the compass in the Mediterranean dates to the 1240s (Khalileh, 2006). Al-Tasa is the term used in medieval islamic scientific texts for the magnetic compass. A treatise on the magnetic compass used for finding the Kibla was compiled by Rasulid Yemeni Sultan al-Ashraf in about 1290 (Karim, 2005).

A number of scholars wrote treatises that were specifically devoted to earthquakes, as did medieval scholars about other catastrophes, such as famine and plague. For example, the third-century philosopher al-Kindi dealt with the occurrence of winds under earth which cause many earthquakes and eclipses, and Ibn Asakir (d. 1176) authored a book of earthquakes (both of these have been lost); the Egyptian polymath al-Suyuti (d. 1505) included a detailed list of earthquakes in his treatise about the subject (Hirschler, 2006).

These authors differed with regard to the explanations that they advanced for earthquakes. Some earlier scholars argued, under the influence of antique pneumatic theories of earthquakes, that they were caused by gases under the surface that could not condense or escape. According to writers such as
al-Kindi, al-Biruni (d. 1050), and Ibn Sina (d. 1037), the increasing pressure led finally to the seismic vibrations of earth and its crust (Hirschler, 2006). These explanations are similar to Aristotle's explanations of earthquakes.

A second group of authors (especially after the 11th century) ascribed earthquakes to God's immediate will and advanced elaborate cosmological descriptions to explain how he caused them. These descriptions focused either on the Mountain Kaf that, in their view, surrounded earth and was linked to it by subterranean tentacles, or on the idea that earth was placed on the horns of a bull that was carried by a fish. According to this group of authors (e.g. al-Suyuti), earthquakes were either the result of deviating behaviour (adultery, usury, and consumption of alcohol) or signs of the approaching Last Judgment, an idea that is based on the Qur'anic Earthquake Chapter (Hirschler, 2006). Strech and Miquel (2005) point out that "Kaf is thought to be the mother mountain of all the mountains of the world, which are linked to it by subterranean tentacles. When God wants to punish a people, or destroy a country, he sets one of these tentacles in motion, thereby causing an earthquake."

\section{Modern era for geophysics}

Serious work on geomagnetism began in 1600 with the publication of William Gilbert's De magnete. By that date, navigators knew that their compass needles sometimes pointed at an angle to true north (declination) and that sometimes they inclined from the horizontal (dip) (Laudan, 2003a). Until the late nineteenth century no institutionalized discipline of geophysics, the physics of earth, existed. Most geophysical efforts responded to specific national interests, relying heavily on government funding (Laudan, 2003b).

In the eighteenth century, empirical geophysical work gradually displaced speculation (to determine the figure of earth). Researchers turned to problems of earth's magnetism, earth's gravitational field (gravity anomalies), and seismology in addition to this work. By the early 20th century, geophysicists clustered in their own societies and institutes (Seismological Society of Japan, The geophysical laboratory of the Carnegie Institution of Washington; The American Geophysical Union) (Laudan, 2003b). The word Geophysik, in german, was first used in 1834 by Julius Fröbel (Good, 2000). The word geophysics appeared in print only a few times between 1834 and the 1880s. An 1848 edition of the encyclopedia Meyers Großes Conversationslexikon included the article "Geophysik", perhaps written by Fröbel (Good, 2000). 


\section{Geophysical ideas and institutions in the Ottoman Empire}

Ottoman science emerged and developed on the basis of the scientific legacy and institutions of Seljuk Turks. It greatly benefited from the activities of scholars who came from Egypt, Syria, Iran, Turkistan, which were homelands of some of the most important scientific and cultural centres of the time. The Ottomans preserved and enriched the cultural and scientific heritage of the Islamic world, giving it new dynamism and vigour. In the seventeenth century, contacts with Europe became closer and Ottoman knowledge of the West came through translations made from European languages; personal observations by Ottoman ambassadors who paid official visits to Europe and modern educational institutions established in the 18th and 19th centuries (Ihsanoglu, 1998).

In Istanbul, the study of geophysical sciences started by at least 1727. In that year, the magnetic declination angle was successfully measured as $11.5^{\circ}$ to the west by the Turks. It is possible that this starting date goes as far back as 1600 . In 1600, 1625 and 1695, in Istanbul, the magnetic declination angle was measured respectively by Krugeras, Fournier and Chazales. It was also measured by Gautier at Istanbul, Marmara Island and Canakkale in 1820, by Gautier at Sinop and Trabzon in 1824, by Fisher at Izmir in 1829, and by the Russian researchers at Luleburgaz and Dimetoka in 1829 (Sipahioglu, 1957; Ozdogan et al., 1981). The variation of the declination at Istanbul from 1600 to 1947 is given by Ozdogan et al. (1981).

Before these years, there are various treatises in which a compass is mentioned, such as Da'irat al-Muaddel, which means 'Equatorial (Semi-circle) of the Turkish Admiral Seydi Ali Reis (Karim, 2005; Wiedeman, 2005; Sipahioglu, 1957; Dizer, 1977). His other book is Kitab Al-Muhit Fi Ilm'al-Eflak Va'l Abhur (Book of the Regional Seas and the Science of Astronomy and Navigation) which contains information on navigation techniques, such as using the compass (Sipahioglu, 1957). Information on how to use a compass is also given in the Kitab-i Bahriye of Piri Reis and in other books but this may not mean that the magnetic declination angle was generally known.

In the Kitab-i Bahriye (The Book of Navigation) of Piri Reis, there is also a Turkish poem concerning the compass in 1519:

Vara bir kuse karar ide heman Ol simal yildizidir bil bigüman Kim bu tasa var Simalin nispeti Ol sebebten meyl ider gör kudreti

\section{Translation:}

When it turns and comes to a halt You may sure that it points to the north star This stone is northward-looking Behold the power of God, for the stone turns that way

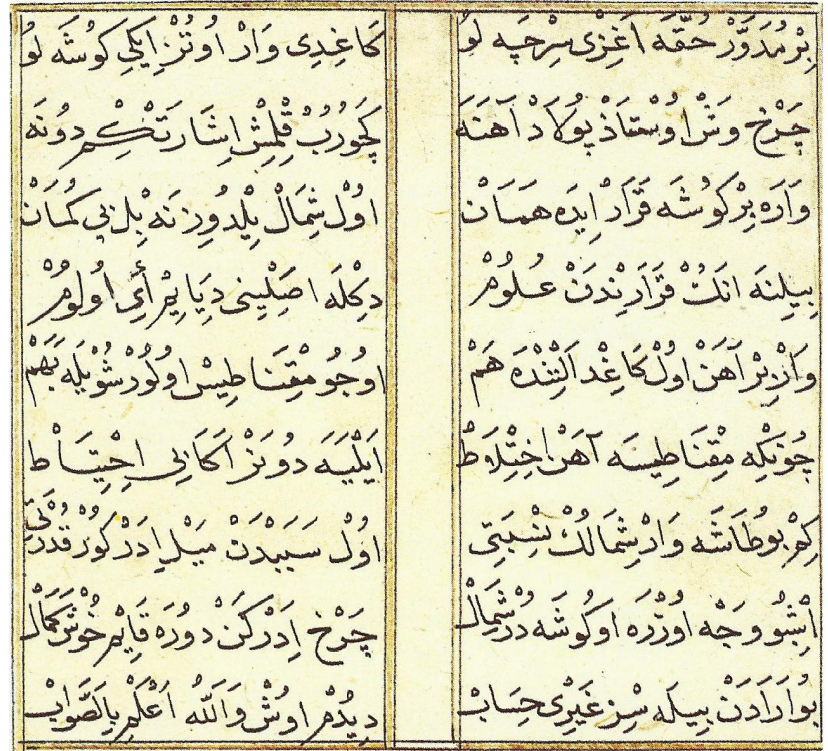

Figure 2a. A poem about the compass in Kitab-lBahriye.

Translated by Bragner (1988).

In this Turkish poem (see Fig. 2a for the original form of this poem), Piri Reis explained that the compass was oriented to the north due to the North Star (Sipahioglu, 1957). This is an idea of the medieval thinkers and scientists. The first scientific book relating to geophysics is the book Fuyüzat- $i$ Miknatisiye (The Benefits of the Compass) that was translated and printed by Ibrahim Müteferrika in 1731. The original name of this book is The Longitude and Latitude Found by the Inclinatory and Dipping Needle etc. and was written by W. Whiston in 1721 (Demirel, 1982). The subject of this book is earth's magnetism. In this book (see Fig. 2b) the magnetic dip compass was mentioned and the ideas known in Europe were summarized. The origin of the magnetic field of earth as given by Gilbert and the secular variations of the declination angle in London and in Paris were explained. From Equator to pole, the variations of dip angle were also explained.

Direct and indirect geophysical and earthquake books in Turkey before 1920 are given in Tables $2 \mathrm{a}$ and $\mathrm{b}$. The cover pages of some important books related to the geophysical sciences are given in Fig. 3a-f. There is little information concerning the geophysical sciences in the book Cihannuma written by Katip Celebi and in the book Maarifetname that was written by Ibrahim Hakki Erzurumlu, although these books are not wholly geophysical books. In the Ottoman Empire, Cihannuma, of Katip Celebi, is one of the earliest books printed. It was printed in 1776 by Ibrahim Muteferrika, who is also the first official printer in the Ottoman Empire. In this book, in the section concerned with geomagnetism there is some information on the origin of the geomagnetic declination angle and on its variations of time and space. Cihannuma 


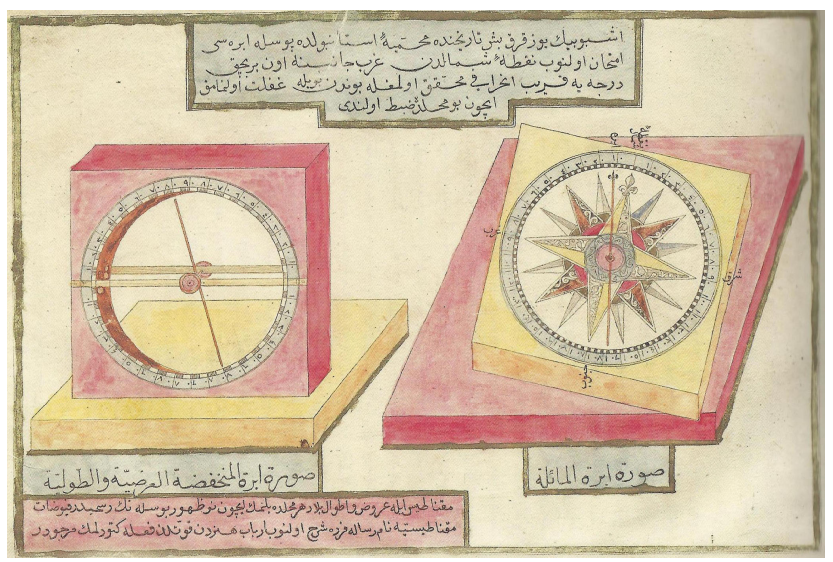

Figure 2b. Inclining and dipping needle illustrations from the book Fuyuzati Miknatisiyye (Istanbul University Library).

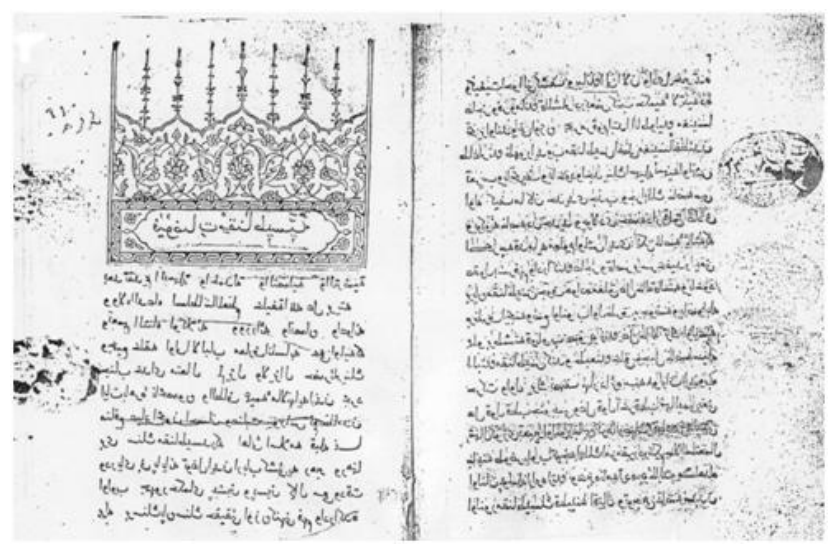

Figure 3a. Füyuzat-i Miknatissiye (The Benefits of the Compass) written by Ibrahim Müteferrika in 1731 (from Istanbul University Library).

is mainly a geographic work. It consists of two parts: in the first part, it describes the seas, the rivers, and islands (or physical events), and in the second part, it describes the countries and cities (or social events). There are two editions of the "Cihannuma": the first,written in 1648, was mainly a cosmographic book and it was dependent on the theory of four elements (Aristotle). There is no information on western countries in this edition. In the second edition, in 1654, it used both eastern and western data sources such as from the works of Mercator, A. Ortelivus and P. Cliiver. With one world map and approximately 100 detailed local maps, this work drew on the system of the Ptolemaic universe.

The volcanic origin of earthquakes was explained in the book Marifetname (Book of Gnosis) which was a compilation and commentary on several sciences by Ibrahim Hakki Erzurumlu. In this book, earthquakes were explained by natural forces. This was one of the first modern approaches to earthquakes. In this book, Ibrahim Hakki Erzurumlu also explained other geophysical events such as weather and the wa-

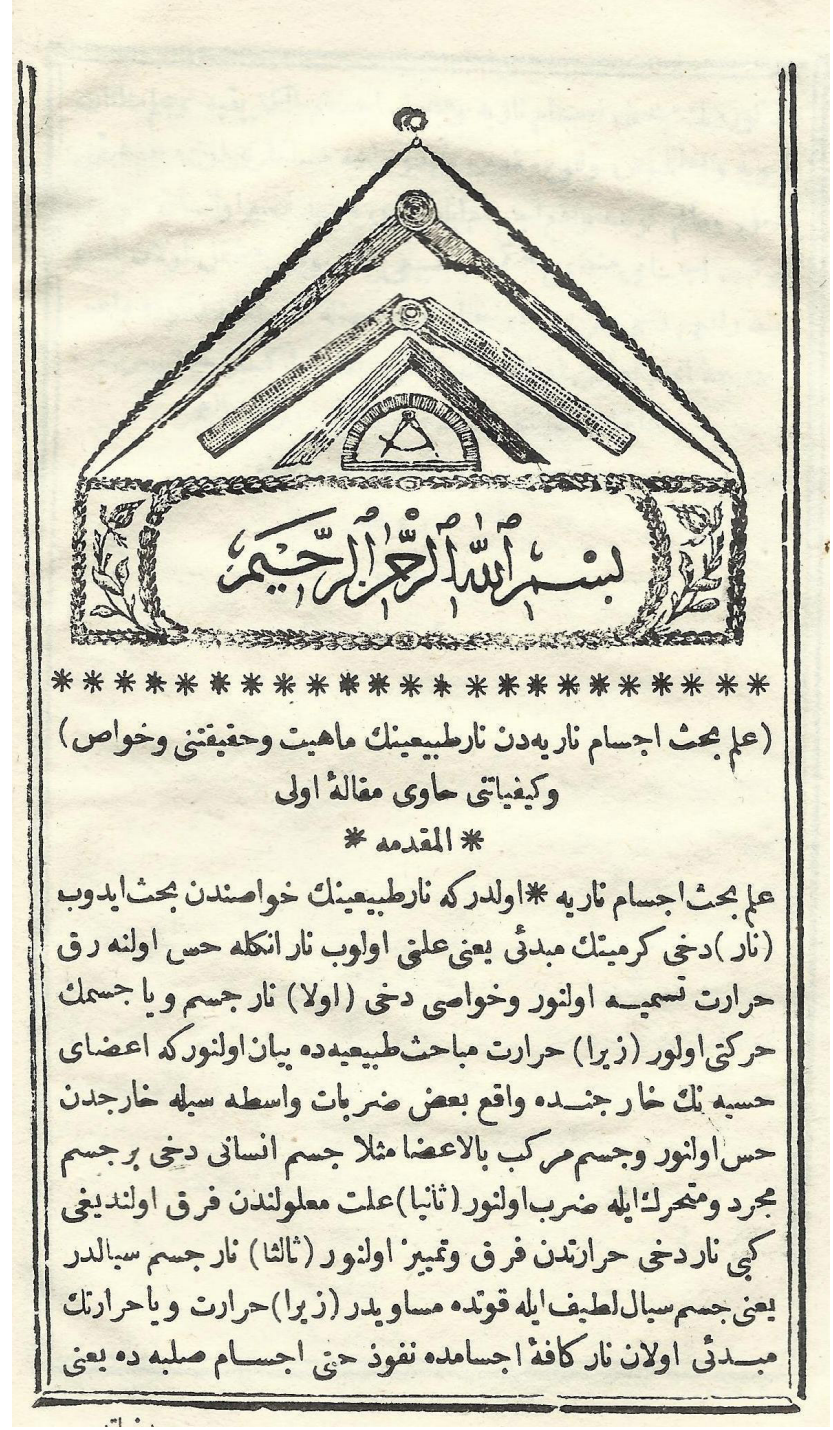

Figure 3b. Cover page of Mecmua-i Ulum-i Riyaziye (Collection of Mathematical Sciences) written by Hoca Ishak Efendi in 1750 (from my own library).

ter cycle; their structure and impact on soil, oceans, water and the human body. There is also some information on the shape of earth and on mathematical geography. The explanations for earthquakes in Ottoman science are introduced by two main theories: those of Aristotle and those of the Islamic geographer Suyuti. In the first explanation, earthquakes are trapped underground by expanding gases. In the second, the cause of earthquakes is the Kaf Mountain.

In Istanbul, the year 1868 is one of the most important for geophysical sciences because an observatory named Rasathane-i Amire was installed in Istanbul. I. Coumbary was the first director of this observatory. In this observatory, the first systematic geophysical measurements - such as meteorological, seismological and even gravimetrical - 
Table 2a. Direct and indirect geophysical books written in Turkey before 1920 (Özçep and Özçep, 1994).

\begin{tabular}{lll}
\hline Name of the book & Author & Date \\
\hline Kitab-i Bahriyye (Book of Navigation) & Piri Reis & 1519 \\
Cihannüma (Universal Geography) & Katip Celebi & 1776 \\
Füyuzat-i Miknatissiye (The Benefits of the Compass) & Ibrahim Müteferrika & 1731 \\
Maarifetname (Book of Gnosis) & Ibrahim Hakki Erzurumlu & 1757 \\
Mecmua-i Ulum-i Riyaziye (Collection of Mathematical Sciences) & Hoca Ishak Efendi & 1750 \\
Asar-i Bakiye (Immortal Works) & Salih Zeki & 1900 \\
Hikmet-i Tabiye (Physics or Natural Philosophy) & Salih Zeki & 1900 \\
\hline
\end{tabular}

Table 2b. Some Turkish books about earthquakes between 1800 and 1900 (İzgi, 1997).

\begin{tabular}{|c|c|c|c|}
\hline Name of the book & Author & Date & Subjects \\
\hline Risale-i Zelzele (Essays on the Earthquakes) & Recep El-Kostantini & 1726 & Written after the 1719 Istanbul earthquake \\
\hline İşaret-Nüma (Signe-Indicator) & Gokmen-zade Haci Çelebi & 1855 & Describes the Bursa earthquake \\
\hline $\begin{array}{l}\text { Hareket-i Arz ve Esbab-i Zuhuru Hakkinda... } \\
\text { (About the Earthquake and its Occurrence) }\end{array}$ & Ahmet Tevfik Kocamaz & 1890 & About Earthquakes \\
\hline $\begin{array}{l}\text { Hareket-i Arz'a Dair Birkaç Söz } \\
\text { (Some Words about the Earthquakes) }\end{array}$ & Halil Ethem & 1894 & About earthquakes \\
\hline $\begin{array}{l}\text { Zelzele Hakkında Malumat } \\
\text { (Some Information about the Earthquake) }\end{array}$ & Ali Muzaffer Bey & 1895 & About earthquakes \\
\hline Hareket-i Arz (Earthquakes) & Salih Paşa-zade Abdullah Mazhar & 1897 & About earthquakes \\
\hline
\end{tabular}

were made. The aim of the observatory was mainly weather forecasting and earthquake recording. The observatory was located in Pera (now, Beyoglu, Istanbul). In the beginning, there were more than 10 meteorological stations. Data collected by the observers were sent to Paris, Berlin, Vienna, St Petersburg and Hungary observatories and the data from these observatories were received in the same way (Kandilli Observatory, 1961; Sipahioglu, 1957; Malin and Isikara, 1997). The first absolute gravity measurement in the Ottoman Empire was carried out in Eskişehir and in Bakırköy (Istanbul) in 1896 by Gilbert Defforges (Deforj Pasha) (Şerbetçi, 1999).

In 1894, a major earthquake occurred in Istanbul. The government of the Ottoman Empire invited G. Agamennone, an Italian seismologist, to Istanbul. Agamennone installed a group of seismographs in Istanbul and worked there for 2 years. He established the earthquake department of the Ottoman Empire and wrote a bulletin of earthquake studies which includes 1894 and 1895. By the beginning of 1896, he had approximately 10 papers on places in Turkey (for example Aydin, Pergamon, and Balikesir) (Brinkman, 1981; Sipahioglu, 1957). After the 1894 earthquake, there is the correspondence between the government of the Ottoman Empire and several European States to establish the Earthquake Department in Kandilli Observatory and to buy seismographs for this observatory. Figure 4 shows the samples of seismographs that were proposed. Also, a report on the 1894 earthquake was prepared by D. Egenistis. In the report there is an isoseist map of the 1894 earthquake (Fig. 5 and 6).
After Coumbary left the observatory, the next director of the observatory was Salih Zeki, one of the most important natural scientists and mathematicians of this period. Salih Zeki authored many books. One of these is Asar-i Bakiye which gave a history of science. In Hikmet-i Tabiye (Natural Science or Physics) also written by Salih Zeki bey, there is some information about geomagnetism. He mentioned one experiment of magnetic declination made in 1892 in Istanbul. The magnetic declination angle was $3.30^{\circ}$ to the west. The observatory had been relocated to Macka (a region of Istanbul) by this time. In 12 March 1909, the religious of the Ottoman Empire made an anti-revolution. In this antirevolution, some instruments of the observatory, such as seismographs, were broken by the religious (Sipahioglu, 1957; Dizer, 1993a and b).

Mehmet Fatin Gokmen, one of the pioneers of modern systematic geophysical and astronomical work, was appointed to the directorate of the observatory (Rasathane-i Amire) and was charged with its reorganization. The aim of Gökmen was the development of the observatory as a modern geophysical and astronomical institution. The location of the observatory was moved to Kandilli (now, Kandilli Observatory and Earthquake Research Institute of the Bogazici University).

Although the observatory began systematic meteorological observations in 1911, there had been meteorological records in Anatolia since 1839. However, these are individual records. Some of these were recorded in the cities of Istanbul, Izmir, Trabzon, Tekirdag, and Merzifon. The oldest records were made at the foreign schools (for example Saint Benoit) in Istanbul between 1839 and 1847. These recorded local 


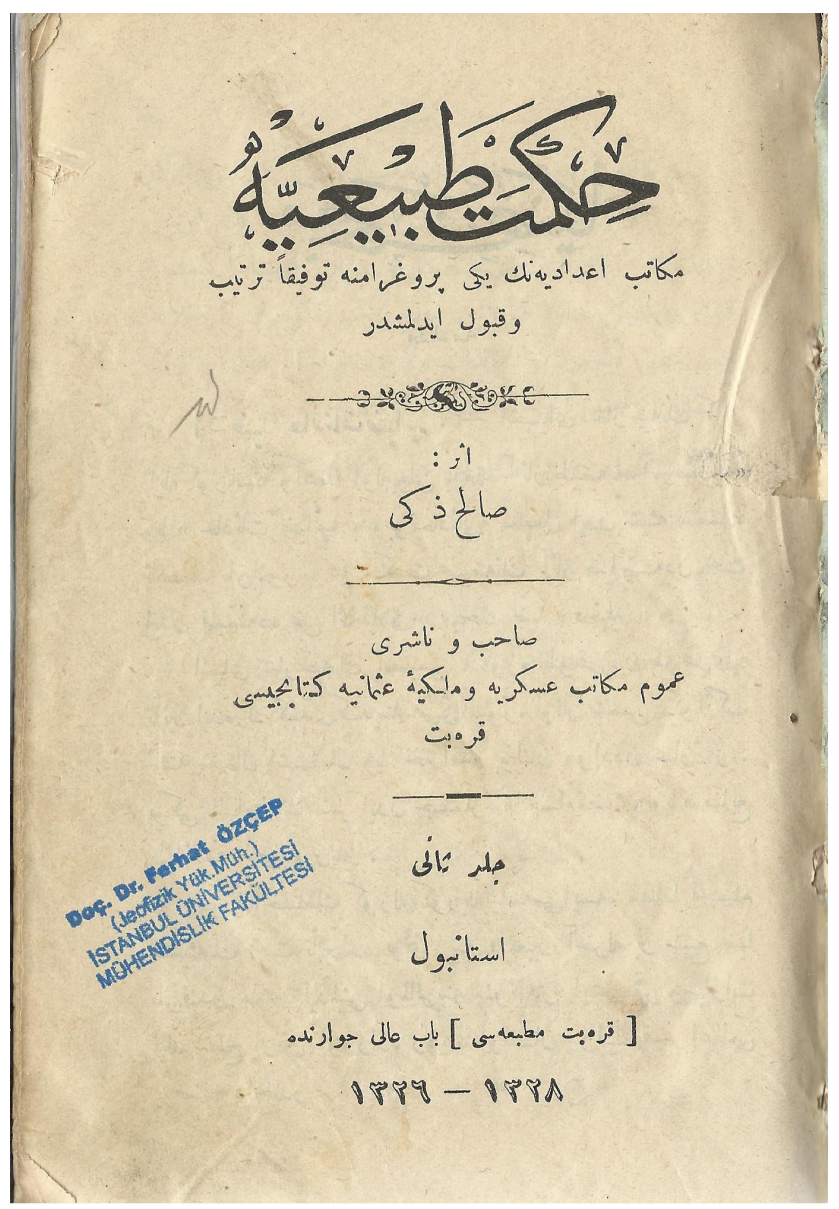

Figure 3c. Cover page of Hikmet-i Tabiye (Physics or Natural Philosophy) written by Salih Zeki in 1900 (from my own library).
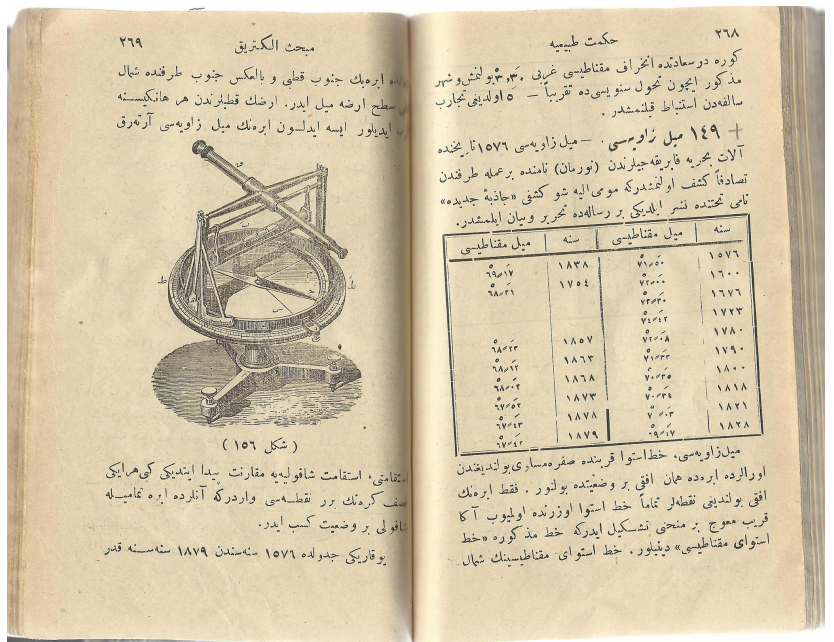

Figure 3d. A page from Hikmet-i Tabiye (Physics or Natural Philosophy) (from my own library).

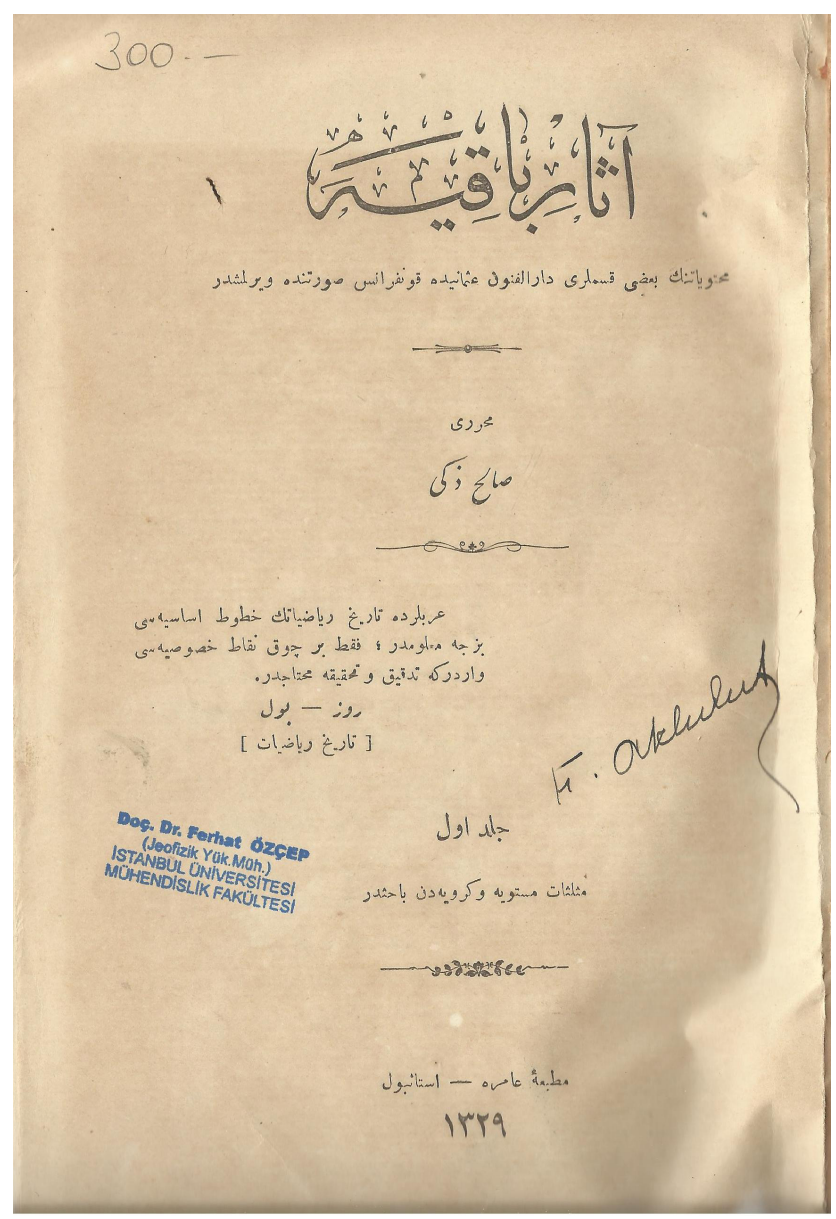

Figure 3e. Cover page of Asar-Bakiye (Immortal Works) written by Salih Zeki in 1900 (from my own library).

temperatures. There are also observations of temperature, pressure and humidity that were made by P. de Tchichatchef and by A. Wiguesel in Haydarpasa (Istanbul), in Trace and in the different cities of Anatolia (Cölaşan, 1960; Dizer, 1993b).

Oceanographic studies (Artüz, 1990) in the Ottoman Empire were started by Luigi Ferdinando Marsigli in Bosphorus (Istanbul) in 1681. Marsigli's book cover page and map are shown in Fig. 7. The first Turkish oceanographer was Ahmet Rasim, who carried out an expedition in the Bosphorus and the Marmara Sea between 1894 and 1896.

In the last period of the Ottoman Empire, the science of geophysics was considered as one of the natural sciences - such as astronomy, mineralogy, geology, etc. - and these sciences were grouped as a part of physics and chemistry (Akyol, 1940).

One of the most important educational institutions of the Ottoman Empire is Mühendishane-i Berri Humayum (School of Engineering). Hoca Ishak Efendi, who is the most notable teacher or rector of this institution, explained the origin of earthquakes in his book named Местиа-i Ulum-и Riyaziye (Handbook of the Mathematical Science, 1750). Here he 


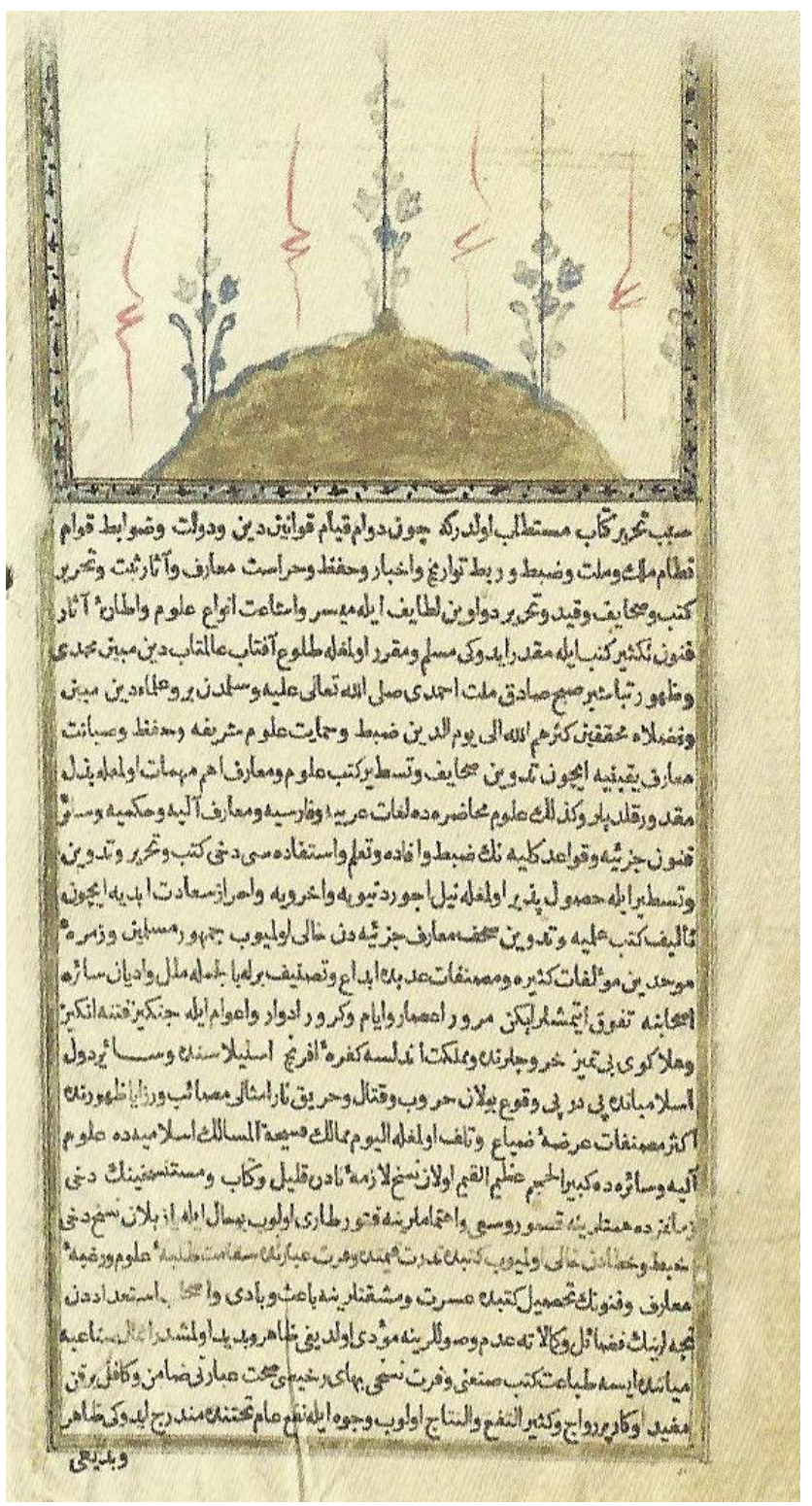

Figure 3f. Cihannüma (Universal Geography) written by Katip Celebi (Haji Khalifa) in 1776.

explained that earthquakes originate from natural processes such as volcanic eruptions. This is a short but relatively modern approach of the origin of the earthquakes.

The first meteorological lecture, in Istanbul was presented in Halkali Ziraat Mektebi (Agricultural School of Halkali) by Allahverdi Efendi in 1909 (Akyol, 1940).

Between 1884 and 1886, M. Antoin D'Abbadie made magnetic measurements in 32 locations such as Egypt, the Arabian Peninsula, the Aegean Sea coasts, Greece and Italy. In May 1885 and in June 1885, he measured geomagnetic declination and horizontal field strength in Iskenderun, in Izmir and in Istanbul. His data were published in Annals $d u$ Bureau Des Longitude of France in 1890 (Sipahioglu, 1957).
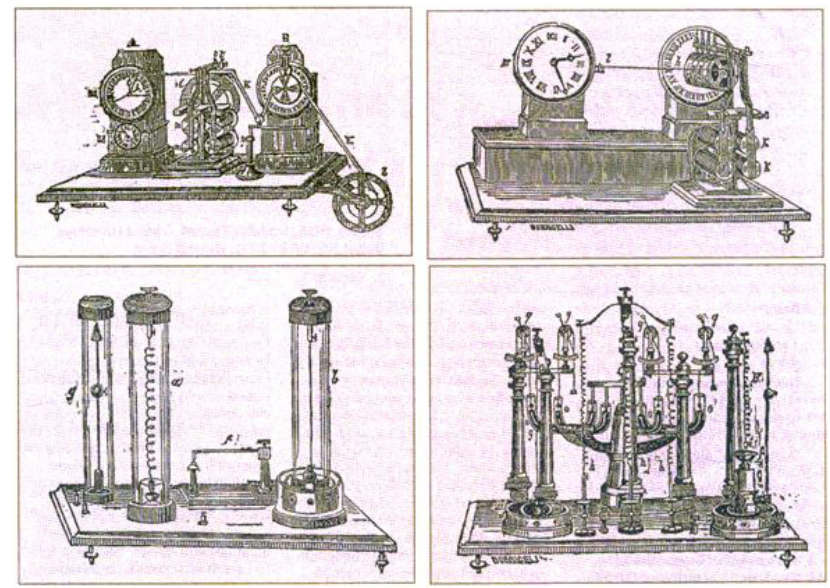

Figure 4. Examples of historical seismographs proposed by the Ottoman Government (taken from the Ottoman Archive of the Turkish Republic).

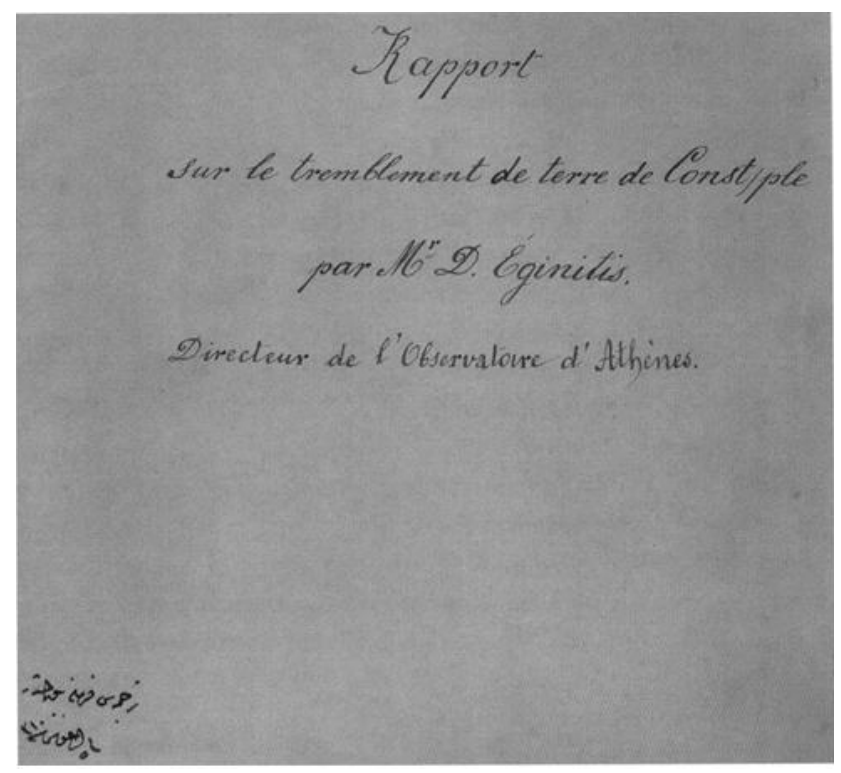

Figure 5. Cover page of The Report on the 1894 earthquake, prepared by D. Egenistis.

As a summary of this scientific activity and geophysical events in Turkey, some of the geophysical books and papers published in Turkey before 1920 are listed in Table 3.

\subsection{Some geology books in Ottoman Empire}

There are books concerning the geology in the Ottoman Empire (Erguvanl1, 1978). There are 24 books in the Ottoman period written with Arabic script in Turkish (Erguvanll, 1954, 1978). These books were written for high-school and university (Darulfunun) students and $70 \%$ of these books have been translated into Arabic, English, French and German. The other $30 \%$ were written by Turkish contributors 
Table 3. Some geophysical books and papers on Turkey before 1920 (the historical period) written by several researchers (after Sipahioglu, 1957; Çölasan, 1960; Akyol, 1940; Brinkman, 1981).

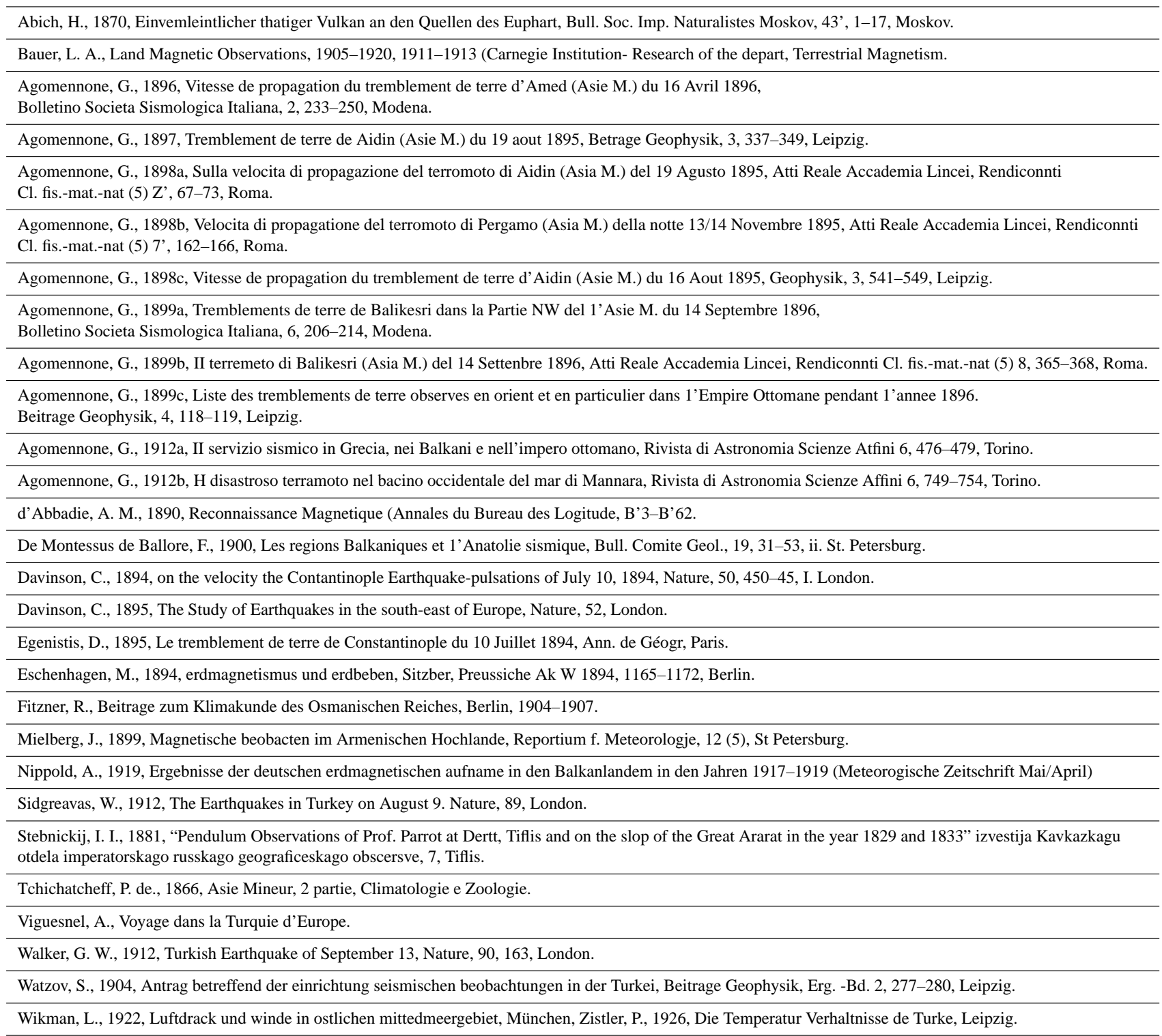

with geological examples of Turkey. Some of these books are given in the following:

1. 1852 - Mehmet Ali Fethi: Ilmü Tabakatülarz. Arabic translation. Contains 158 pages and 1 figure; published by Darül tıbatüatül Amire.

Properties of this book: written for University students. It includes two main parts (theory and practice). It first used the term "geology" in Turkey.

2. 1875 - Abdullah Bey (Translated by Dr. İ. Lütfi). İlmülarz vel Maadin. Contains 584 pages and 129 figures; published by Mektebi Tıbbiyei Şahane Matbası, Istanbul.
Properties of this book: lecture notes of Abdullah Bey from the School of Medicine and translated by Dr. BinbaşIIbrahim Lütfi. This book was the first lecture book in Turkey.

3. 1889 - Halil Ethem: Ilmi Maadin vel Tabakatülarz. Contains 304 pages, 128 figures and 1 coloured map. Published by Mihran matbası, Istanbul.

Properties of this book: it concerns geology and mineralogy.

4. 1899 - Halil Ethem: Muhtasar Ilmi Tabakatülarz. Translated from Hochsetter-Bisching. Contains 165 


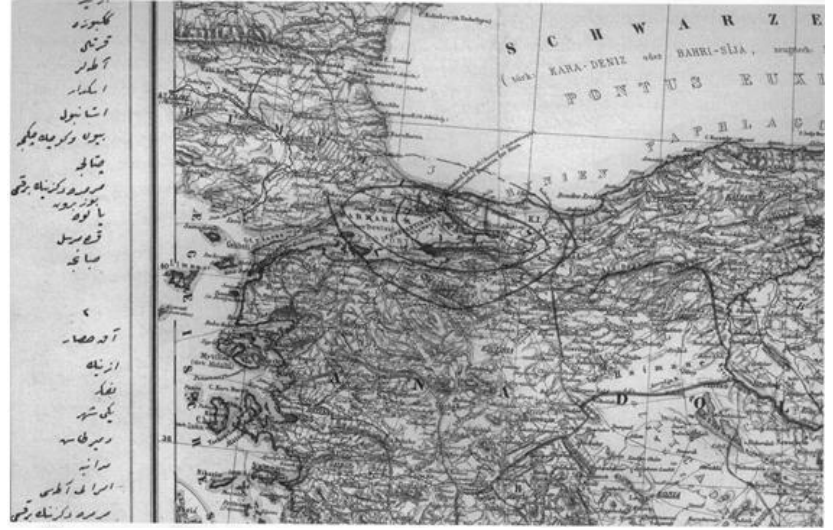

Figure 6. Isoseist map of the 1894 earthquake, prepared by D. Egenistis.
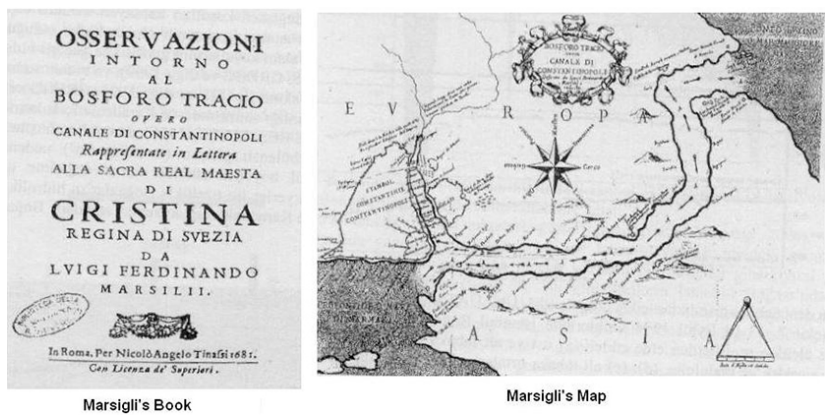

Figure 7. Marsigli's book on Oceanographic studies and Map of the Bosphorus.

pages and 59 figures. Published by Mahmut Bey Matbaas1, Istanbul.

Properties of this book: the original book was written in German and translated. This book was prepared for high-school students. There is some knowledge and examples of the geology of Turkey.

5. 1907 - Hüseyin Remzi: İlmütabakatülarz. Contains 106 pages and 50 figures. Istanbul.

Properties of this book: this book was prepared for high-school students. There is some information about Turkey's geology.

6. 1844 - Mehmet Nazım: Kitabi Tabakatül Arz vel Maadin. Published by Mektebi Tibbiyeyi Şahane Matbas1.

7. 1887 - Hüseyin Remzi: Illmülarz vel Maadin. Translation, contains 48 pages.

8. 1887 - Ali Fuat (tranlated by Dr. Yüzbaşı): Tabakatülarz. Contains 298 pages, 48 figures and 2 tables. Istanbul. (Originally written by A. Geike)

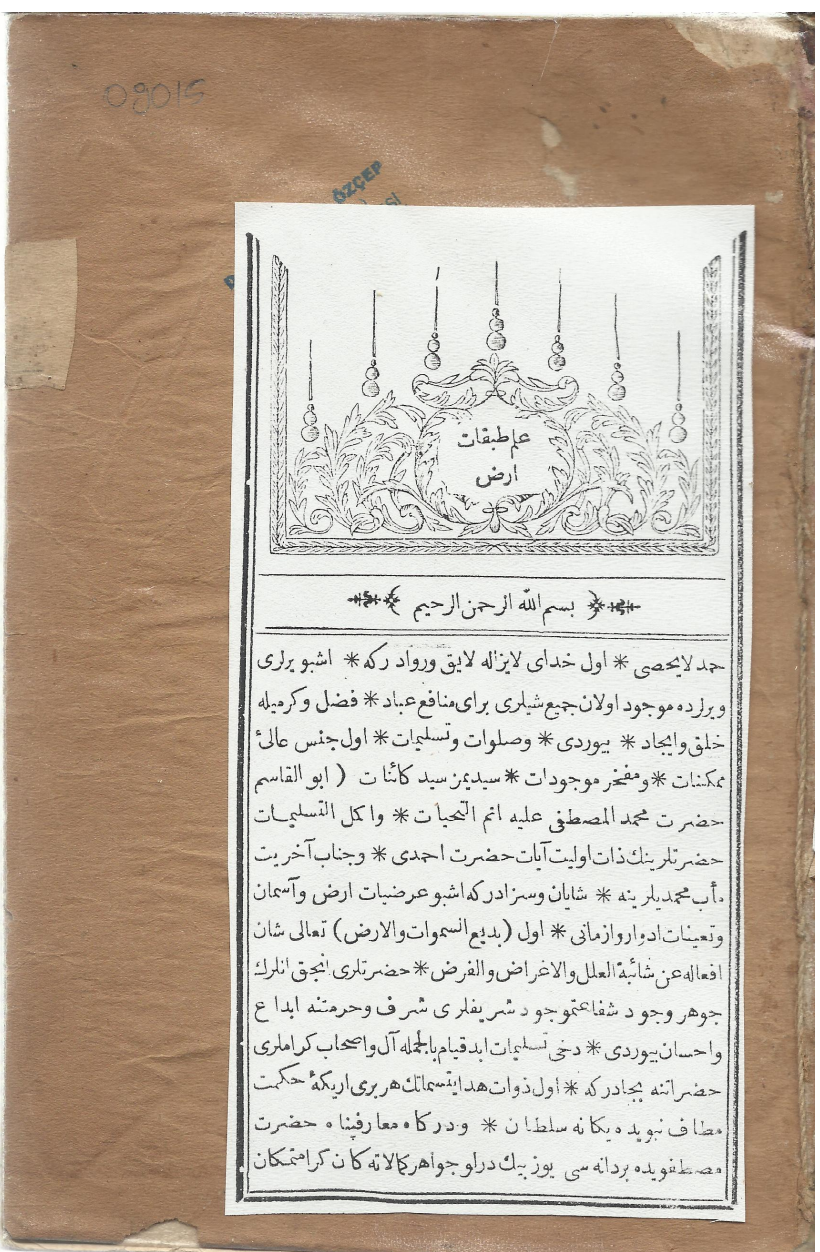

Figure 8. First geology book in the Ottoman Empire, written by Mehmet Ali Fethi: Illmü Tabakatülarz.

9. 1887 - Le Coq (Lökok Paşa, translated by Rusçuklu Şevki): Ameli İlmüarz. Published by Mühendishanei Berri Humayun Matbasi; contains 101 pages and 8 figures. Istanbul.

10. 1889 - Mahmut Esat: İlmüarz vel Maadin. İzmir.

11. 1889 - Mahmut Esat: Madeniyat ve Tabakatül Arz.

12. 1889 - İbrahim Lütfi: İlmi Arz. De Lapperent's Precise de Géologie was translated by Ibrahim Lütfi; contains 496 pages and 122 figures. Published by Mahmut Bey Matbaası, Istanbul.

13. 1896 - Fahri Paşa: Ilmülarz vel Maadin. Translated from French.

14. 1898 - Ali (Dr. Binbaşı): Telhüsü İlmü Maadin.

15. 1898 - Esat Feyzi: İlmülarz vel Maadin. Contains 272 pages and 170 figures; published by Mahmut Bey Matbaası. 
16. 1906 - Dr. Rifat: Tabakatülarz.

17. 1909 - M. Sadi: İlmi Arz. Contains 196 pages and 119 figures. Published by Matbai Hayriye. Istanbul.

18. 1911 - Ebül Muhsin Kemal: Yeni İlmi Arz. Contains 166 pages and 97 figures. Istanbul.

19. 1912 - Mazhar Hüsnü: İlmi Arz. Istanbul.

20. 1913 - Hüseyin remzi: İlmi Arz. Contains 92 pages and 75 figures. Istanbul.

21. 1914 - Hüseyin Remzi: Illmi Arz. Contains 84 pages and 45 figures. Istanbul.

22. 1922 - Ali Kenan: Madeniyat Dersleri. Istanbul.

23. 1923 - Harun Reşit: Yeni Illmi Tabakatülarz. Contains 270 pages and 185 figures. Istanbul.

The cover page of the first geology book in the Ottoman Empire is shown in Fig. 8.

Acknowledgements. I would like to express my special appreciation and thanks to D. Cole as Topical Editor for editing the language of our manuscript. I express my deepest thanks to Y. Altinok at Istanbul University for his review and suggestions for our paper. This project was partly supported by Istanbul University project no. YP-16/150198.

Edited by: D. Cole

Reviewed by: Y. Altinok and one anonymous referee

\section{References}

Adams, F. D.: The Birth and Development of the Geological Sciences, Dower Pub., New York, 506 pp., 1954.

Adıvar., A.: OsmanlıTürklerinde İlim, Ankara, 1942.

Akyol, İ. H.: Tanzimat Devrinde Bizde Coğrafya ve Jeoloji, Maarif Vekilliği yay, Ankara, 1940.

Artüz, İ.: Oseanografi Ders Notları, I.T.Ü. GI.DB Fak. Sayı, 22, İstanbul, 1990.

Bragner, R.: Kitab-i Bahriye: Piri Reis, English Translation, Ministry of Culture and Turism of Turkey, Ankara, 1988.

Brinkman, R.: Türkiye Yerbilimleri Bibliografyası: 1825-1975, Bölüm 1, Türkiye Dışında yayınlanan Yerbilim Yapıtları, TÜBITTAK Yay., Ankara, 1981.

Çölasan, E.: The Climate of Turkey, Ankara, 1960 (in Turkish).

Dampier, W. C.: A Shorter History of Science, Meridian Books, New York, 353 pp., 1959.

Demirel, S.: Book of "Fuziiyati Miknatisiyye" of Ibrahim Mliteferrika, D.T.F.C. Ataturk'ün 100. dogum yilma armagan dergisi, 265-330, Ankara University Printinghouse, Ankara, 1982 (in Turkish).

Dizer, M.: The Dairat al-Muaddal in Kandilli Observatory, and some remarks on the earliest recorded Islamic values of magnetic declination, JHAS, 1, 257-262, 1977.
Dizer, M.: Rasathane-i Amire, Journal of History of Science of Turkey, 16, 3-10, 1993a (in Turkish).

Dizer, M.: Meteorology in Turkey, Journal of History of Science of Turkey, 21, 3-19, 1993b (in Turkish).

Erguvanl, K.: Ibrahim Ethem Pasa: the First Mining Engineer of Turkey, Geological Bulletin of Turkey, 3, 129-132, 1954 (in Turkish).

Erguvanlı, K.: Jeoloji Mühendisliği Öğretiminin Türkiye'de Gelişimi, 25. Yılda Maden Fakültesi Kılavuzu, Maden Fakültesi Yayını, İstanbul, 1978.

Good, G. A.: The Assembly of Geophysics: Scientific Disciplines as Frameworks of Consensus, Stud. Hist. Philos. M. P., 31, 259292, 2000.

Hirschler, K.: Earthquakes, in: Medieval Islamic Civilization, An Encyclopedia, edited by: Meri, J. W., Routledge Taylor \& Francis Group, New York, 2006.

Ihsanoglu, E.: Modernization efforts in science, technology and industry in the Ottoman Empire (18th and 19th Centuries, in: The Introduction of modern Science and Technology to Turkey and Japan, edited by: Gunergun, F. and Kuriyama, S., International Research Center for Japanese Studies, Kyoto, 15-35, 1998.

İzgi, C.: OsmanlıMedreselerinde İlim, 2. Cilt, Tabii İlimler, İz Yayıcılık, İstanbul, 1997.

Kandili Observatory.: 50th Anniversary, (1911-1961), Guide Book, National Education Printinghouse, Ankara, 1961 (in Turkish).

Karim, A.: Magnetic Compass: Scientific Texts, in: Encyclopedia Islamic Science and Scientists, edited by: Zaki Kirmani, M. and Singh, N. K., Global Vision Publishing House, India, 195-196, 2005.

Khalileh, H.: Navigation, in: Medieval Islamic Civilization, An Encyclopedia, edited by: Meri, J. W., Routledge Taylor \& Francis Group, New York, 555-557, 2006.

Laudan, L.: Terrestrial magnetism, in: The Oxford Companion to the History of Modern Science, edited by: Heilbron, J. L., Oxford University Press 2003a.

Laudan, R.: Geophysics, in: The Oxford Companion to the History of Modern Science, edited by: Heilbron, J. L., Oxford University Press, New York, 2003b.

Liner, C. L.: Greek Seismology: Being an Annotated Sourcebook of Earthquake Theories and Concepts in Classical Antiquity, Department of Geosciences, University of Tulsa, 1997.

Malin, S. and Isikara, A.: Istanbul Kandilli- 50 years, 1AGANews, 36, 3-4, 1997.

Ozdogan, I.: Foundation, Development and Future of the Geophysics Department at the Faculty of Sciences of Istanbul University, Jeofizik, IV, 12-16, 1975 (in Turkish).

Ozdogan, I., Orbay, N., and Isikara, A. M.: Evolution of Geomagnetic Data Obtained Istanbul since 1600, Istanbul Earth Sciences Review, 1, 71-73, 1981.

Ozemre, A. Y. (Ed.): Development of the Natural Sciences of the Faculty of Science at University of Istanbul in the Modem Period of Turkey and their contributions to international scientific works, University of Istanbul Pub., Istanbul, 1982 (in Turkish).

Özçep, F. and Orbay, N.: History of the Geophysical Sciences in İstanbul (Turkey) since 1600, in: GEOMAGNETISM AND AERONOMY: With special historical case studies, edited by: Schroder, W., Science Edition, Comm. History IAGA/History Commision DGG, ISSN:0179-5658, 111-122, 1997. 
Ozcep, F. and Ozcep, T.: The Geophysical Studies in Turkey before 1923: as a History of Science Approach, Jeofizik Bulteni, Bulletin of Geophysical News and Communications of Geophysical Engineers of Turkey, 23, 22-16, 1994 (in Turkish).

Schroder, W.: Why research into the history of geosciences, EOS, 62, 521-522, 1981.

Şerbetçi, M.: Türk HaritacılığıTarihi (1895-1995), Harita Mühendisleri OdasıYayını, Ankara, 1999,

Singer, C.: A Short History of Scientific Ideas, Oxford University Press, Great Britain, 525 pp., 1959.

Sipahioglu, O. N.: Geomagnetic works in Turkey, Turkish Physical Society Pub., Ankara, 1957 (in Turkish).
Soysal, H., Sipahioglu, S., Kolcak, D., and Altmok, Y.: The Historical Earthquake Catalog of Turkey and adjoining Area, the Scientific and Technical Council of Turkey, Ankara, 1981.

Strech, Z. and Miquel, C.: Kaf, in: Encyclopedia Islamic Science and Scientists, edited by: Zaki Kirmani, M. and Singh, N. K., Global Vision Publishing House, India, 2005.

Wiedeman, E.: Magnetic Compass, in: Encyclopedia Islamic Science and Scientists, edited by: Zaki Kirmani, M., Singh, N. K., Global Vision Publishing House, India, 195-196, 2005.

Yildirim, C.: Science: its meaning and method, Middle East Technical University Pub., Ankara, 1971.

Zahoor, A.: Muslim History : 570-1950 C.E, ZMD Press, Gaithersburg, 2000. 